Andra Kalnača

A Typological Perspective on Latvian Grammar 



\section{Andra Kalnača}

\section{A Typological Perspective on Latvian Grammar}

Managing Editor: Anna Borowska

Associate Editor: Helle Metslang

Language Editor: Uldis Balodis 
Published by De Gruyter Open Ltd, Warsaw/Berlin

Part of Walter de Gruyter GmbH, Berlin/Munich/Boston

\section{(cc) BY-NC-ND}

This work is licensed under the Creative Commons Attribution-NonCommercial-NoDerivs 3.0 license, which means that the text may be used for non-commercial purposes, provided credit is given to the author. For details go to http://creativecommons.org/licenses/by-nc-nd/3.0/.

Copyright (C) 2014 Andra Kalnača

ISBN 978-3-11-041130-0

e- ISBN 978-3-11-041131-7

Bibliographic information published by the Deutsche Nationalbibliothek

The Deutsche Nationalbibliothek lists this publication in the Deutsche Nationalbibliografie; detailed bibliographic data are available in the Internet at http://dnb.dnb.de.

Managing Editor: Anna Borowska

Associate Editor: Helle Metslang

Language Editor: Uldis Balodis

www.degruyteropen.com

Cover illustration: (c) leva Kalnača 